困を示す。これは漂白クラフト紙の上にラテノクスを 二回コーチングしたものが，コーチングの雷量によつ ていかに水蒸気透過率が変化するかを示したものであ る、コーチングは一回で厚くするよりる薄くコーチン グを何回るする方が有效である。

これらラテークスによるフィルムの水蒸気透過率が 前記第 2 項記載のフィルムに比較して大であるのは, ラテノクスが水溶性の乳化㓮や分散肪を含有している からであるが，それでもな抢かり極めて有効な水蒸気， 湿気の防止をな寸すのである.

\section{3. ラバー，その他としてのサラン}

サランはラバーとしても文特殊の材料である. 硫黄 を含まないアミン采化合物によつて硫化され，通常の ゴムライニングと同樣な方法でライニングされる. 第

第10表 サランラバーの性貿

$\left(20^{\circ} \mathrm{C}\right)$

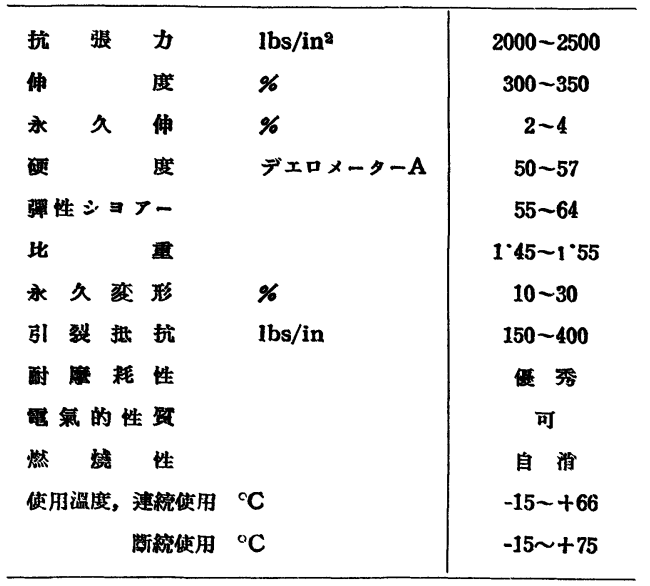

10表はサランラバーの一般的性質を示したるのである. 化学的には脂肪属炭化水素類, 炭化水素の㙁素化合物, 低粐アルコール，大部分の無機酸，油，溶剂等に硦め

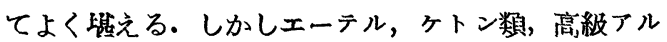
コール，フミノ化合物には不適である、従つてサラン ラバーは耐薬品性の大なること, 耐摩耗性の大なるこ とによりて, 屈蝕性の夜体の輸送, タンク, 反応容器 等のライニングやダイヤフラム等に広く使用される。

その他印刷インク製造装置用材料，扣よひプレス口 ーラーとしてる使用されている. 第 2 項記載のサシン パイプは，化学的に耐萝品性の点からみれば充分であ るが, 鋼管の内側をサランラバーで内張りすることに よつて，パイプよりさらに堅牢性と耐圧性を加えるこ とが州来る。おたバルブや継手類のライニングに使用 される、ラバーそれ自身としていパンキングガスケン 卜等の製造に使用される。特別な場合にはショアー硬 度を90程度まであげることも出来る。

その他, 塩化ビニリデンア・リロニトリル系のサラ ンで,メチルエチルットンのごときある種の溶肪に可 溶なるのがある.これはコーチング用材料としてのみ ならす，包装，ラッカー，耐底蝕性ペイント，人造

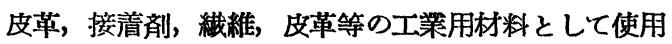
される。この溶液から生成されたコーチングは，溶郕， 油, グリース, 酸, アルカリ等に対する抵抗性は極め て大で，かつ無臭，無味，無毒である. 機械的强度も 大て耐摩耗性む强い。これから生成された 0.001 in. の厚味のフィルムは, 水蒸気透過率が 0.15 て殆儿ど湿 気を通さない。

\title{
含浸用珪素樹脂ワニスについで
}

椎 原庸**,二井林一昆 ${ }^{* *}$, 大溝 義昭 ${ }^{* *}$

\section{1.はじめに}

20世紀の化学者の手によつてシリューンが誕生して 以来シリコーンが保有する耐熱, 而寒性, 耐薬品性, 電気絶縁性等の数多の特性は従来の材料に不满を抱い ていた応用面に新しい分野を開拓して来た・シリコー ンがその出現以前には予想もされない位の特性を有し ていることは, シリューンが全く人工によつて作られ， 天然にはその片鱗さえ見られない新合成物层であり， その骨格構造の特異性に起因尗る為であることが明ら かにされているが，以下その概哭と私見を迹べて応用

\section{研究者に凟したいと思 3.}

\section{2. シリコーンにっいて}

シリコーンの定義扣よひその分野については10年程 前に工業化された米国に物いては勿論, 最近では我国 に特いてもあらゆる佮度から研究討䉝されて括り，そ の都度斯界の権威により十二分に解說され盐した悠が あるのでここに防ひ繰返すの曷をさけるが，本稿延行 上必要な部分について少しく説明を加えて置きたい。

シリコーンは樹脂状物，油状物，ゴム状物に大別さ れるが，原料の配合および製造工程をか觉ることによ り天然物に見られる殆んぞすべての状熊をとりらる。

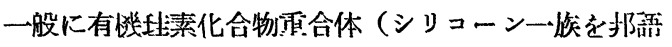


にするとこのよろに長くなるので以後シリコーンそ略 す) は他の合成樹脂々同樣製造工程の便'它上，単量体 （モノマー）と重合体（ポリマー）に二大別されるが， 前者は理砂を還元した金属珠素に有刘な触媒成分を加 え，これに有機化合物（普通はメチルクロライド，エ チルクロライド等の有機ハロゲン化物が使用される） 単独または触媒がスを加熱时蒵入反応せしめて製造す るのが一般的でり，生成物は有㭫基の結合割合によ つて次の樣に各種の物質が生ずる.

金属理素 $(\mathrm{Si})+$ トロゲン化炭化水素 $(\mathrm{RX}) \longrightarrow$

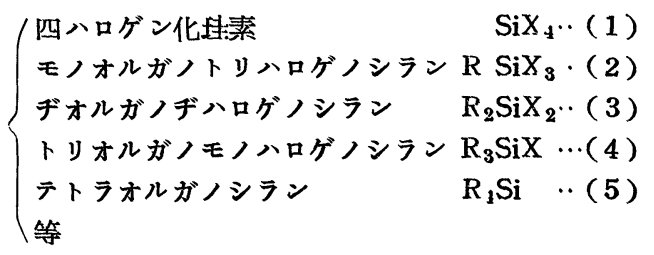<smiles>C[Si](C)(C)CC[Si](C)(C)O</smiles>
よつて固くてもろい珠素塩物貿は可摬性を有し有機溶 郕と混合するよらになる・すなわち<smiles>[R][Si]([R])([R])O[Si]([R])([R])O[Si]([R])([R])O[Si]([R])([R])O[Si]([R])([R])C</smiles>

のごとく有機物と無㙨物の混血览とも称すべき物質と なる. 故に有機物と無機物との比がシリコーンの性能 に大なる影響を有する．勿論前述したごとく Rの種類 によつてあ左右される訳であるが， Rは製品の種類や 目的により事前に決定されることが多い。製造業者は この値をR/Si で表わしているが, この比を決定するむ のは中間体の組成であり第 1 図を見て頂けれは扮分り

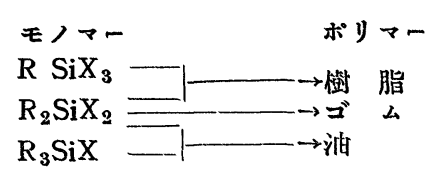

第 1 舆

になると思うが, 樹脂状物小: $\mathrm{R} / \mathrm{Si}=1$ なる $\mathrm{RSiX}_{3}$ とR/ $\mathrm{Si}=2$ なる $\mathrm{R}_{2} \mathrm{SiX}_{2}$ の混合組成物から㷱造されること が普通であるから，R/Si 1・0〜2゙0の間にある，尤む

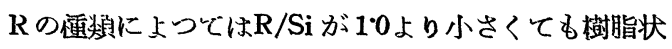
物となる訳であるが，このよらにして R/Si が2末满

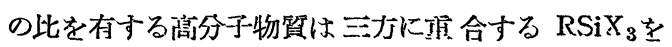

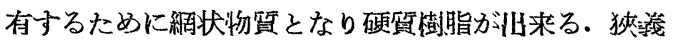
の理索澍脂はこの上らな物質をさす訳であるが， R/Si
この他に塩素塩化水素の混入炭化水素の分解によつ て理素原子に種々の化合物の結合した物賀も合成され るが，生成物（1）は無機物を生じ，（5）は安定“゙重合 しないのでシリューシの彆造には主に（2)一(4) の生 成物が利用される。ここに記したは原料有㙨物によつ て脂肪族, 沙香族等蹥々の化合物が採用されるが，脂 肪族にメチル基 $\left(\mathrm{CH}_{3}\right.$ 一) エチル基 $\left(\mathrm{C}_{2} \mathrm{H}_{5}\right.$ 一) 等の低 級アルキル基, 劳㴡族にはフェ 䫼化されているよろである.

このよらな各種単量体は目的により種々の㓶合に混

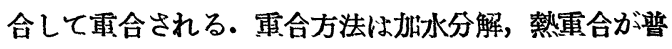
通であるが，この反応によつて中間体は次の反応に示 すような変化を受けて次第に高分子物賀となつて行く.

㫜素と酸素の結合(シロキサン結合)によつて出来た 骨格は無機理酸㙁たる砂やガラス, 水晶, 石英等と同 じものであるが，この轨素に有機物が結合することに<smiles>C[Si](C)(C)O[Si](C)(C)O[Si](C)(C)C</smiles>

か2に近くなる程酸素架橋が少くなつて, 樹脂に柔軟性, 可挃性を生ずるよろになる。同樣に $\mathrm{R}_{2} \mathrm{SiX}_{2}$ のみから 出発するとこれは直鎮状に重合し分子量を著しく高め ることによりゴム状となる. 尤もこれだけではどこま で雨合しても果しがないから, 適当なところで少し網 状にして弾性体とする訳である.油状物はゴム状物を

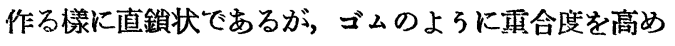
ず $\mathrm{R}_{3} \mathrm{SiX}$ 的ごとき一個の反応基を有する化合物を加え て鎖の長さを制限する. 故に油状物については雷合度 の低い程 $\mathrm{R} / \mathrm{Si}$ が大になり， R/Si=3が限度で，これは 最も重合度の小さい2 2量体すなわち $\mathrm{R}_{3} \mathrm{SiOSiR}_{3}$ である.

以上のような工程で製造されたシリコーンはこのよ らな構造をるつているためその性質は無機物と有機物 の雨方の特性を併有しているが次表にシリコーンの特 微と欠点を列与しょろ。

第 1 表 シリコーンの特失

\begin{tabular}{|c|c|c|c|c|}
\hline & 特微 & 起 & 点 & 起 \\
\hline 1 & 酎熱性，酎答纰 & 称晓成分 & 㙨的的强度小 & 慜譏成分 \\
\hline 2 & 撥 水 性 & 有機战分 & 强盟基々弱心 & 慜教成分 \\
\hline 3 & 表面 洲 性 & 有眆成分 & & \\
\hline 4 & 雪氣㹦豚性 & 呅成分 & & \\
\hline 5 & 酎酸化性, 梸㷋訬: & 慜機成分 & & \\
\hline
\end{tabular}

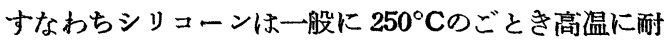

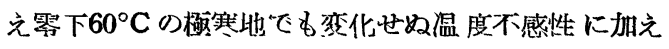
てパラフィンに匹敞する撜水性を有寸るため，電気絶

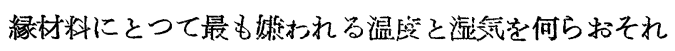

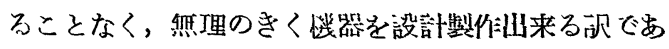


る. 更に天候, 気儌, 紫外線, 有害がス, 化学薬品等 の劣化条件に対しても抵抗力が大で工策材料として物 理的化学的難点を殆んど克服している.

\section{3. 含漫用珪素樹脂ワニス}

一般に電気絶縁用ワニスとして使用される物質学大 別すれば次の四種になる。

\section{1. 導体絶螕用 2. 積層板・成型品用 \\ 3. 含浸用 \\ 4. 仕上用}

これら各種ワニスは目的の相漟によつて性状む恃性をむ 異なつているが本稿に括いては第三の含浸用ワニスを 主眼として期素樹脂の性筫を明らかにしたいと思う。

近年シリューンの特性を電気絶縁物として利用すべ く多方面からの検葀が加えられているが，その結果は

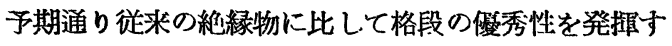
ることが認められたので, 従来のA種括よひB種絶縁 に対し，シリコーン絶縁はH種絶縁と称して別途規格 が設けられている。

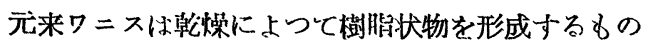
であるからシリコーン一族の内ワニスとして利用州来 るものは R/Si く2なる狹義の科素樹脂である.しかし ながら理素樹脂は熱硬化性であり，樹脂化したものは 容易に楁剤に溶けないので，製造工，程に招いては始め

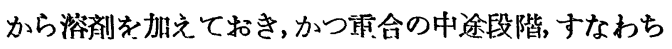

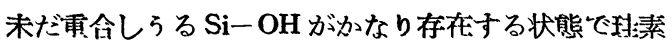
樹脂ワニスとして制品化している。この場合前述した 上らにRの種類， $\mathrm{R} / \mathrm{Si}$ の值により相当性留の然化が見

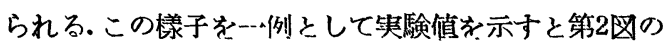
よろになる。才なれち Rとして有機基がアルキル基の

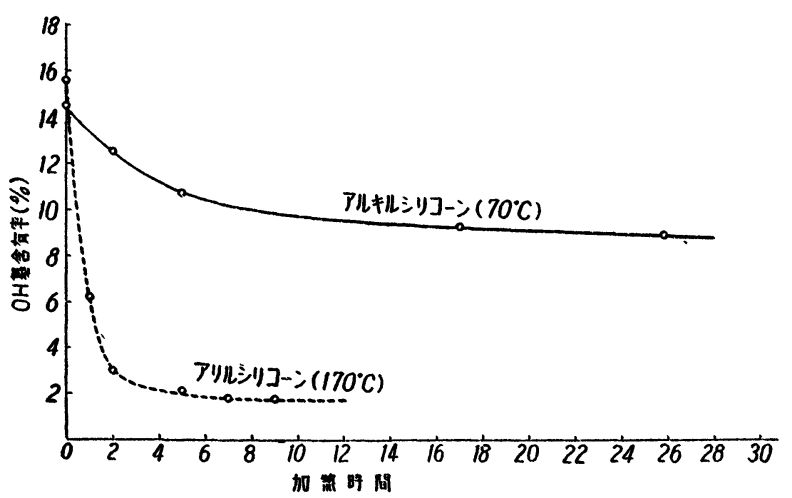

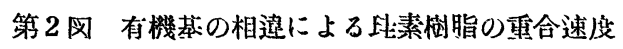

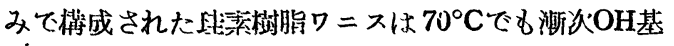
を減少して古令休となるに术しフュニル基を主体とす るシリニーン心 $170^{\circ} \mathrm{C}$ 以上に加然才ることにより $\mathrm{OH}$ 基の隇少が認められるがその特性としてアルキル禾に

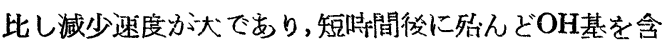
有しなくなる。この事实は侯沭寸る含浸用䢁素樹脂ワ こスの附着性に重大な影響を及住するのと撨定される。
理素樹脂ワニスの性状をまとめて見ると

1. $\mathrm{R} / \mathrm{Si}$ 值が小さい程樹脂化速度が大で，樹脂は 固く脆いが， R/Si が 2 に近い程高温鹿て長時間 加熱しないと樹脂化しない。

2. Rがフルキル基のみの場合は電合により硬化す る一方(熱硬化性)であるが，フリル基が入ると常 温で固化しても熱可塑性のため高温で軟化する.

3. 雨合の際フリル采怔念速に $\mathrm{OH}$ 基を減少于るが, アルキル系は減少率が小さい。

となり，目的により種類の異なつた理祘樹脂ワニスを 月小なけれは满足な結果を得がたい。導体絶縁用理素 樹脂ワニスは現在相当量の需給があり，製品も略々满 足すべき状態にあるが含浸用に対しては一心絶縁工程

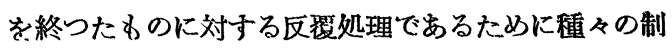
約条件が加わり，かつ絶緑物の完成工程であるため程 素樹脂ワニスの選定にいさ〉か考慮を要すると思われ る.すなおら含浸用ワニスは

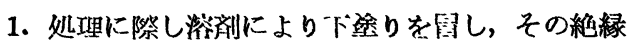
を破壤しないこと。

2. 処理後加䓡䩐燥により粘度が減少せす，漸次上 年し澍脂化すること。

3. 被腹すべき絶縁物に充分含浸附着し, 電気的機 峨的に满足寸べき樹脂を形成せしめらること。 の3つが满足されている必㳅があろ万と思万。各項目 について少し詳細に述べる。

(1) 滨剤の量

球素澍脂は一般に深剂に篔されることが少ないるの であるぶ, 含昆操作に先行して行われる導休・がラス織 布・ガラス布テープ・積曆板・成型品等に対する処

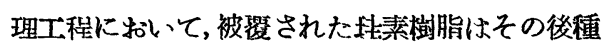
々㙨械的操作が加えられるためにシロキサンの 可合を完結せしめず, 完全樹脂化の少し手前に标 かれていることが多いために溶剤によつて客出 の位除性を有している。この点を解決するため には含浸ワニスの溶斉量を少くすそ・すなれち ワニスの煛度を高める必要がある。筆者の経験 では50\%で下鈊を冒すワニスも，少くとも70\%に 潤縮寸れは侵蝕の怙それが殆んどないと云える。

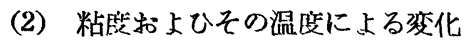

含浸処理後樹脂附着監の多いことが含浸ワニ スとして好滴であるのけ可論であるが，それを炏定す るのはワニスの粘度である.一般には006多主 12 ポア ズとも2:5 ポフズ以下とも云われているか，垁験によ れは044 ポアズ以下‘゙は㱠んど附着しないが，粘度を 0.8 万至 1 ポアズにした所略々满足しらる附着量を得, これより大になる程附着量む增した。含浸処理後の加 熱によりワニスは澄用を揮散し再合して迣第にその粘 


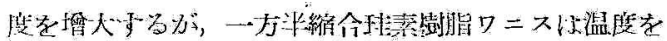

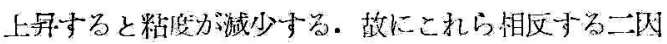

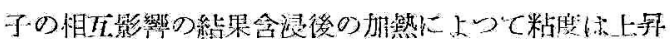

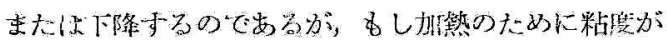

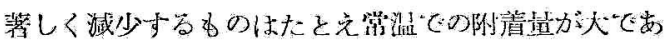

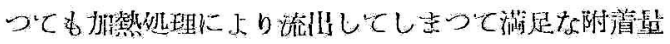

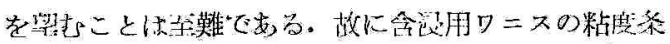

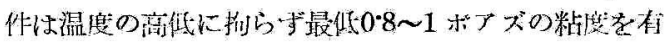

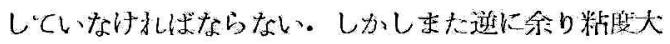
なる時以絶緑がラス在テープ等下刘しての含被能力が

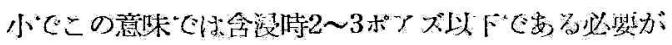

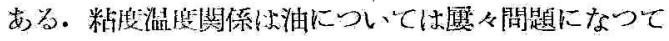

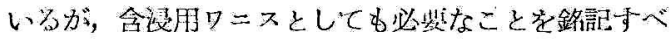
きと思れれる.シリコーンとしてこの粘度温娄閶係老

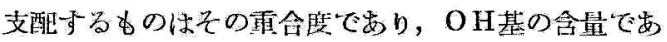
る. 西合度の低い、ワンは温度に上る粘度变化が等し

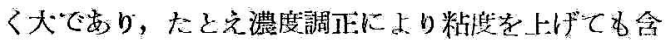
浸用には適しない.このワニスの溜展老变化させるこ となく溶復》東而合せしめることにより粘度が上升

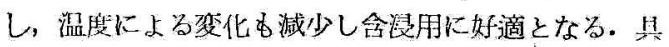

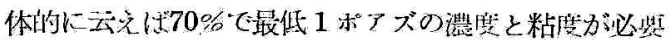

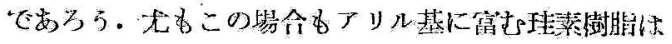

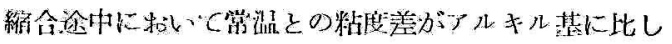

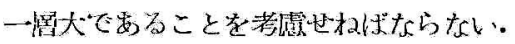

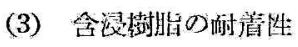

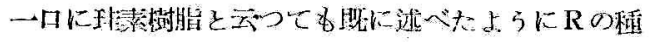

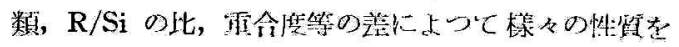

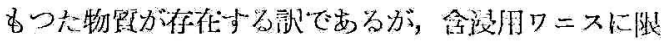

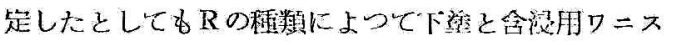

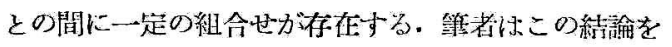

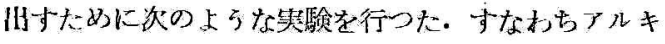
ル系、アリル系の二程の上記条俳老满足す名上らな含 浸用ワニスに対し，同樣にアルキル柔とアリル系二稙

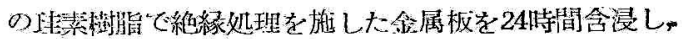

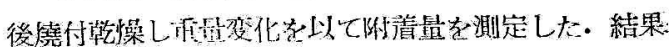
堂 2 表に示主.

符2哀 有機基の落による含浸用球素

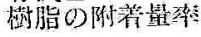

\begin{tabular}{|c|c|c|}
\hline 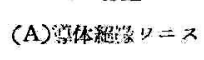 & 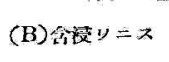 & 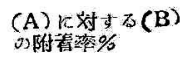 \\
\hline$r x \neq x$ 采 & アルキル系 & $407 \div 7$ \\
\hline ノルキル系 & フリル乘 & $520^{\circ} 9$ \\
\hline ンリル系 & フル几系 & 116.2 \\
\hline 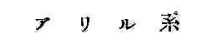 & $T$ y $几$ 系 & $51 \cdot 3$ \\
\hline
\end{tabular}

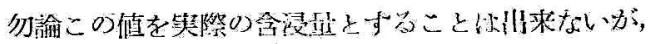

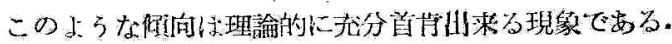

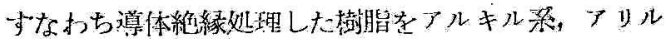

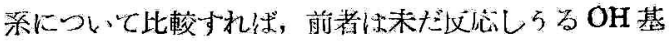

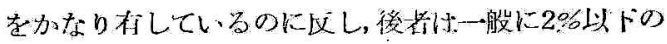

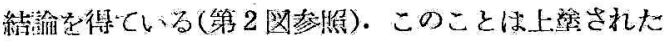

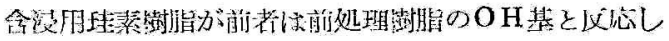

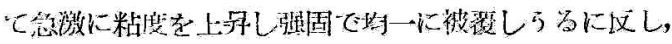

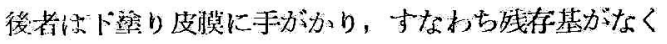

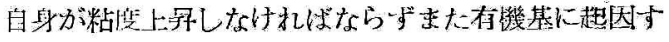

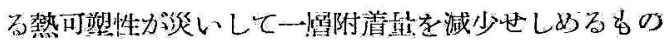

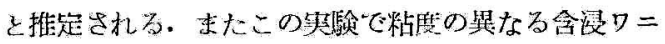
スを用いたとこみいつれる粘度(すなわち任合度)の大

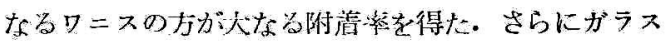

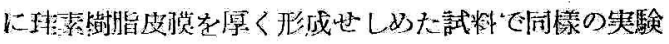

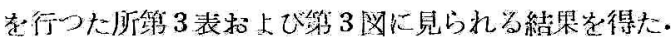

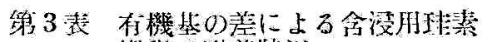

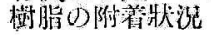

\begin{tabular}{|c|c|c|}
\hline 猪成澍脂 & 今席ワ二ス & 外 \\
\hline フリル柔 & アルキル系 & 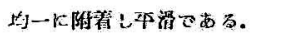 \\
\hline フリル系 & フリル系 & 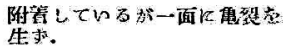 \\
\hline
\end{tabular}

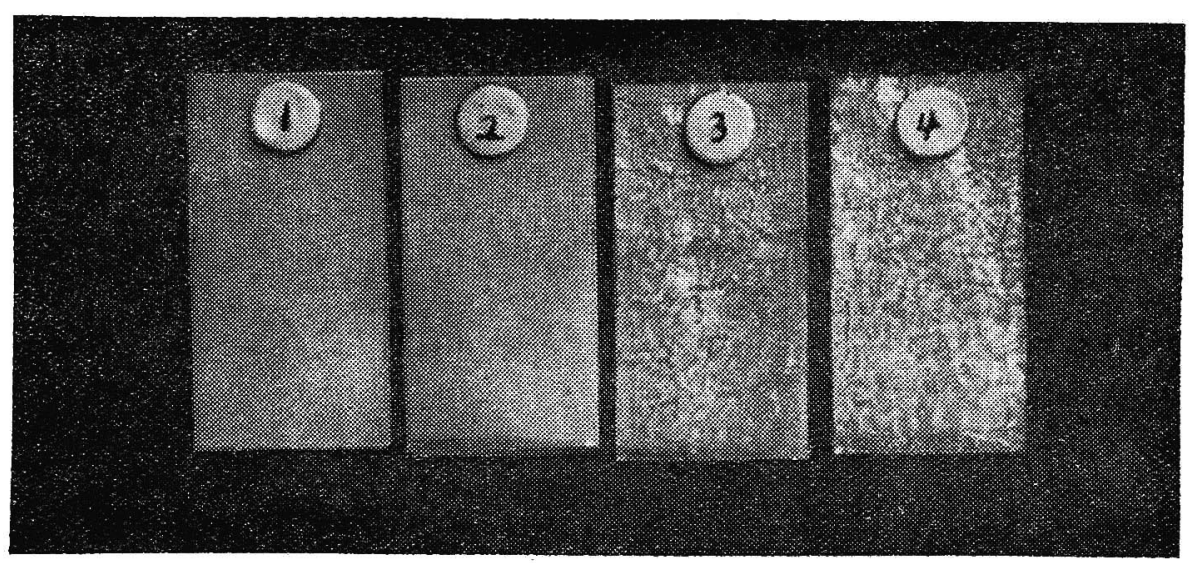

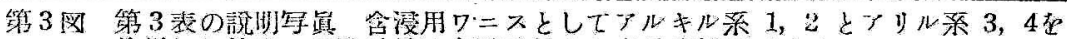

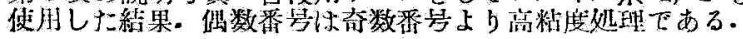


これば一般に導体絶絲用として用いられるアリル系蛣 脂ワニスに対し同系統の含浸用ワニスを用いることは， たと立澍脂が附着しても下筑りを冒し，均一な含浸澍 脂皮膜を作らないのに反し，アルキル系はそのおそれ が全くないことを示している. 本実験についてばさら に詳細な央験を継続中であるが，以上姴約小れば含曼 用珪素樹脂ワニスとしては濃度和よひ粘度の一定以上 を有し，才でに大部分貣合し，粘度の温度に対する影 饗が小ぐかつ前処理樹脂を专すことなく附着性のよい
ものを選定せねはならない。

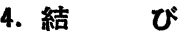

種々の形状恃性とその价用を有するシリコーンの内, 本稍ではH種規格としての電気絶縁物に対する令淩用

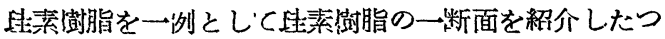

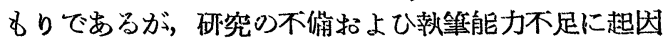

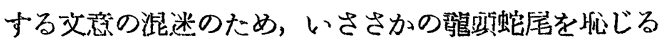

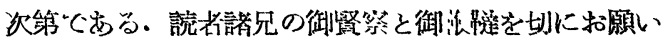
ナる.

\section{ビニール系合成樹脂の建設工業への応月 ${ }^{*}$}

\section{緒霄}

ビニール系合成樹脂の纽設工䍜への心用は近洔次第 に盛になつて参り,その科類〕多怺である。

これに関して次の三つの型に大别して各一つつつ垁 例を举げてみたいと思ら。

\section{1. 硬質物としての応用}

この心用例としては硬鹠.監化ビニール管につき述べ てみたいと思う。

硬䁈塩化ビニール管とは可塑剂を全く加えないか， あるいは加えてる極く少量含まれている塩化ビニール 管である.これは原料が塩化ビニールを主体としてい るので, 耐化学薬品性, 雪気絶縁性, 歎燃性であると 共に，軽量 (鉄の肸) 美麗（彩色自由）かつ, 熔接, 切断, 折り曲げ等の加工が桖めて容易‘゙゙るのでその 特改を生かして鉛管，鉄管の代りに上下水道管，また は瓦斯管に用いて好適であり，詹蝕の泚しい化学工場， 食品工場, あるいは車輛，船船，建造物等の一般配管， 電線管に適し，優美なため趣穼材料，家具，装飾用等 多方面にわたり使用川来る。

紙面の都合上こつではその中，電線管としての硬貿 堛化ビニール管について説明する。

硬筫㙁化ビニール管は優れた耐赨性，電気䋓縁性， 難燃性等を有し，かつ加工し易く，洒格が比較的低廉 であるから電線管としても有利に利用性来るものであ

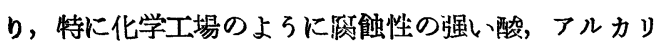
を処理する工場においては従来の金属製電線管は半年 乃至数年の壽命を有するに過ぎす，硬質盐化ビニール 管は好適の配線材料であると考えられる.

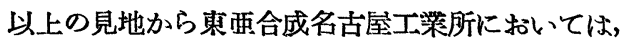
27年初頭以来最む腐玲を受け易い塩酸工場, 液体塩素

\section{大橋 九 萬 雄 ${ }^{* *}$}

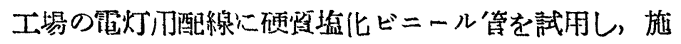
丁法括よひ諸性能につき检䧾を行づいいが，現在迄

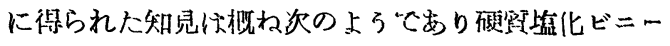
ル管をて線管として使用することは何等支障がないの みならず金属管に比して幾多の長所が認むられた。

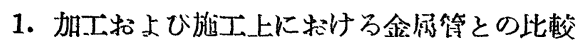
次のよらな特微が認められる。 長所

(a) 切 影

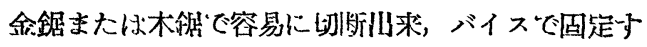
る必笑がない。

(b) 瓦 䏳

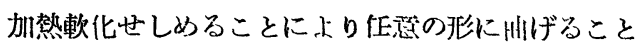
が江来る。

（c）ネシ切り

金属管に比して容易である.工甼け金属管用のもの をその镂伐刃川来る。

(d) 接 続

一方の管端を加熱軟化せしめた後，他管の端を师込

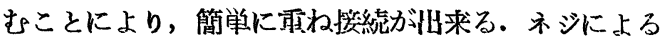
掕続も勿諭可能である.

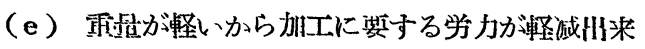
る.

（f）内面が平滑であるから電線被琵を㰾つける心 配が少い。

（g）敷線後管端を加熱して潰寸ことにより口忖線 を固定することが出来るから「ター シナルブ,シング」, 「サービスへ、ド」または「テープ」卷等を省略し得る.

（h）絶緑体であるから接地の必要がなく，妈䉓流 電線に接近しても絶縁性淂膜を設けなくてもよい。

(i) 胳蝕を受けない。

（j）交流回路に招いて電磁的影響を受けないから 单線路にも使用出来る. 